\title{
OSS を用いた音場合成のための残響音付加手法の検討 STUDY ON A METHOD TO MAKE A REVERBERATION PART FOR SYNTHETIC SOUND FIELD BY USING OSS
}

\author{
渡辺充敏*, 木村 翔**, 山口順***, 平野 滋* \\ Mitsutoshi WATANABE, Shou KIMURA, Jun YAMAGUCHI \\ and Shigeru HIRANO
}

\begin{abstract}
This paper proposes that a method to make reverberation part, which considered a time pattern of reflection and head related transfer function, to make time short to get impulse resposes from numerical simulation, which used for synthetic sound field by using OSS, and shows that effectiveness of proposed method through evaluation of difference between measured and operated synthetic sound field by using proposed method as to reverbrarion part.
\end{abstract}

Keywords : OSS, Synthetic sound field, Time pattern of sound reflection, Head related transfer function

O S S、合成音場、反射音時間構造、頭部伝達関数

1.はじめに

近年、コンピュータの急速な性能向上、また数值シミュレーショ ン技術の発展に伴い、基本設計段階から室形状、仕上げ材等の室内 音場を決定する要素を、入力デー夕の変更により様々に変化させ、 比較検討する音響設計支援システムが研究開発され、有効な設計支 援手法の一つになっている。しかし、最終的な仕様の決定に至るま での各段階において、計算出力に基づく検討結果を室形状等に反映 させるための試行錯誤が繰り返されるため、コンピュータを用いた 音響設計支援システムには迅速な処理が要求される。

筆者らも、数值シミュレーション手法掞よび音場の可視化、可聴 化技術 ${ }^{11}$ の開発を進め、これらを統合した音響設計支援システムを 開発してきた。開発してきたシステムにおいて、音場の可視化は主 に検討の初期段階に、音響障害の有無の確認、対策等の基本的検討 のために行う。幾何的手法による計算結果に基づき、室形と応答の 関係等についてインタラクティブな処理を可能とすることで、基本 的検討に要する時間の短縮を図っている。また、音場の可聴化は、 初期段階の幾何的数値シミュレーション手法による基本的検討結果 に、更に合成音場を用いて聴感上の検討を加えるため行うが、可聴化 の際には幾何的手法では予測できない音場の諸特性を受聴者に正確に 提示するため、精度の良い音場の予測計算が必要になる。そのため、
現在、波面積分法 ${ }^{1)}$ と呼称する波動性を考慮した数值シミュレーショ ンを用いて、両耳におけるインパルス応答を算出し、O S S ${ }^{2)}$ を用い て計算結果に基づく音場を受聴者に提示している。波面積分法によ れば、音場合成に必要な全時間インパルス応答計算に要する時間は アルコリスムの工夫により軽減されているが、なお音響設計支援シ ステムの演算系の中で大きな割合を占めており、演算時間短縮が望 まれた。

従来より、音場合成に必要な全時間のインパルス応答算出に要す る時間の短縮のため、数値シミュレーションにより、拡散状態に到 達したと見られる時刻までの初期反射音を計算し、それに別途算出 した残響音を付加する手法が多く用いられている。しかし、初期反 射音の性状を考虑せず、残響音の減衰のみを与えることが多く、初 期反射音と付加する残響音の整合性に問題を残すなど、残響音付加 手法に関する検討は十分ではない。

また、全時間インパルス応答について初期反射音と残響音とに分 けて論じられる事が多いが、インパルス応答の時間構造に着目すれ ば、主に幾何的経路により説明される初期反射音の時間構造が、時 間経過に伴い次第に複雑となり残響音を形成する、と言う連続した 反射音時間構造の変化と見る事ができる。初期反射音から連続する 反射音時間構造を残響音領域において考虑できれば、残響音付加の
* 大林組技術研究所 工修

** 日本大学理工学部 教授・工博

*** 大成建設 (元日本大学大学院) 工修
Obayashi Corporation Technical Research Institute, M. Eng. Prof., College of Science and Technology Nihon Univ., Dr. Eng. Taisei Corporation, M. Eng. 
際の整合性が確保しやすいと考えられる。

初期反射音と残響音との整合性の確保について、高宮らは幾何的 予測手法による反射音の時間間隔がカオスであると仮定し、初期反 射音における時間間隔のリターンマップから残郘音を作成する手法 を示しているい゙。また、西らは、音線追跡法による受音点における 反射音の分析結果から、残響音領域における反射音時間構造をモデ ル化し、全時間の計算結果がよく近似できる事を示し、さらに残響 時間周波数特性の予測精度が残㸷付加の際に重要であることを示唆 している4)。

以上の研究からも、残餖音付加の際には、反射音時間構造および 周波效特性の予測精度が重要であると考えられるが、多大な計算時 間をかけて直接予湘するのは、実際的でない。效值シミュレーショ ンからの音場合成のためには、原音場との聴感上の差異が生じない ような、反射音時間構造等の近似による高速な残響音付加手法の開 発が要求される。

本論文は、音響設計支援システム演算系の中で、大きな時間的割 合を占める全時間インパルス応答算出の計算時間短紑を目的に、残 㸷音領域の反射音時間構造および周波数特性を考虑し、O S S 等の トランスオーラル系を用いた音場合成に適用するための残響音付加 手法を提案している。さらに、タミーヘッドによる実測のインパル ス応答の初期反射音に、本手法を用いて残郎音を付加した音場と、 実測のインパルス応答による音場を用いた一対比較聴感実験結果か ら、本手法の有効性について示している。

\section{2. 寒測による反射音時間瑇造}

実測のインパルス応答測定から、直接、反射音時間構造について 検討を加えるのは困難であると考えられる。そこで、実音場の残響 音領域における反射音時間構造の把握、それに基づく予測手法の検 討のために、正四面体頂点法 ${ }^{5)}$ を用い、実測のインパルス応答から 反射音を表すパルス列として離散化（サンプリング周波数: $48 \mathrm{KHz}$ 、 デー夕数:65536個）し、以降の検討を行うことにした。なお、イン パルス応答からパルス列として離散化した反射音強度の時間変化 を、本稿ではエネルギパルス応答と呼ぶ。

正四面体頂点法は、正四面体の各頂点位置に設置された 4 個のマ イクロフォンにより測定された各インパルス応答に音源出力による デコンボリュージョンの操作を加え、時間分解能を向上させた後、 各頂点間に生じるパルスの時間差等から空間の方向情報を解析しよ うとする手法である。得られた空間情報から短時間指向拡散度の時 間変化を残㗽音領域特定のための手掛かりとしているが、反射音時 間構造の検討においては空間情報は用いず、全方向からのエネルギ パルス応答のみを用いている。

シューボックス型ホール $\left(2000\right.$ 席、 $\left.\mathrm{V}=20500 \mathrm{~m}^{3}\right) 1$ 階中央付近(圆 1）における実測からのエネルギパルス応答を圆 2 の上側に示す。 また、エネルギパルス応答のある時刻 $\mathrm{t}$ に位置する反射音から次の 反射音が現れるまでの時間を、時刻 $\mathrm{t} の$ 反射音に対する反射音時間 間隔として、全反射音に対して算出した。その時間変化をエネルギ バルス応答と合わせて図 2 の下側に示す。なお、反射音時間間隔は 当ホールにおいて正四面体頂点法による短時間指向拡散度の時間変 化から、ほほ拡散状態に移行したみなされる直接音到達後 $180 \mathrm{msec}$. 以降 ${ }^{61}$ について示している。正四面体頂点法による短時間指向拡散

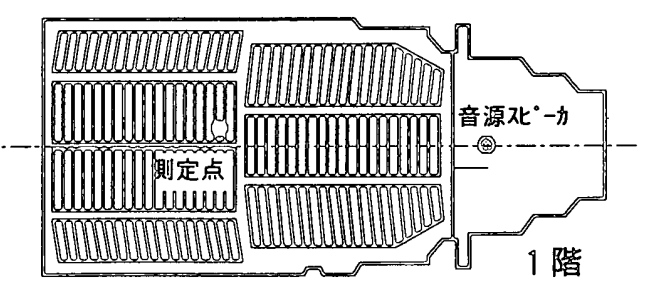

图 1 正四面倈頂点法による測定位罵
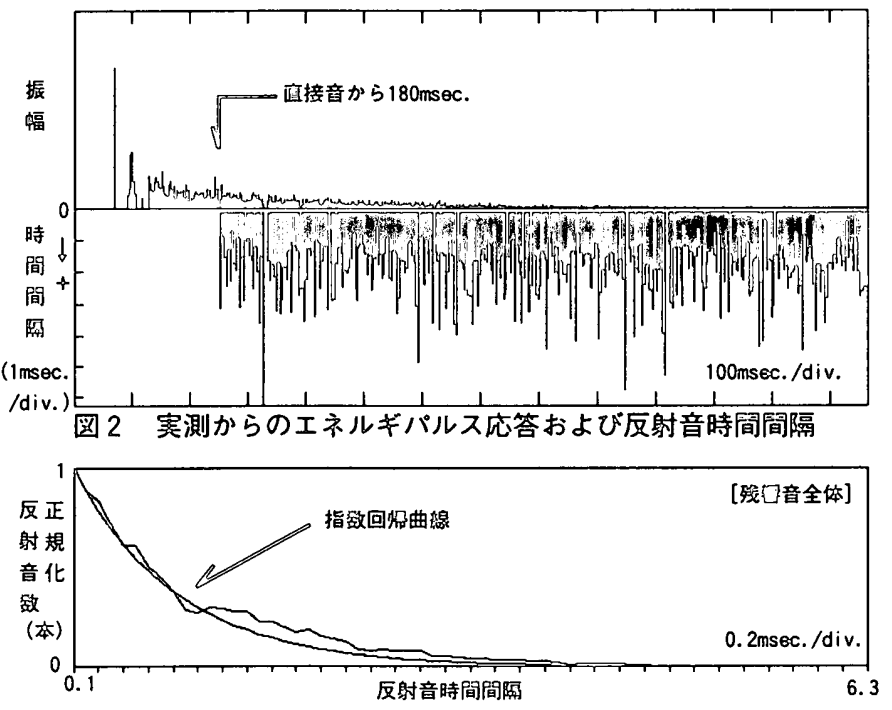

图 3 反癿音時間間隔による度致分布

度は、初期の 0 付近から時間経過と共に上昇し、ある時刻以降（当 ホールでは $180 \mathrm{msec}$.)は、1.0に近づいた值で安定する61。その段 階において室内音場は、ほほ拡散状態に移行したと見なした。

图 2 を見ると、反射音時間間隔は不規則に変動しているが、時間 経過に伴う一定の変化は確認されない。次に、残響音領域における 反射音時間構造の傾向を見るため、反射音時間間隔による反射音数 の度数分布を求めたところ、圆 3 に示す指数分布が得られた。

この残響音領域全体の反射音時間間隔の度数分布と、ある時間 幅を持って切り出した反射音時間間隔による度数分布が、切り出し た時刻によらず同様の傾向を示すのであれば、ある特定時刻の、あ る時間幅内の反射音時間間隔の度数分布から残響音全体の反射音時 間構造の傾向を捉えることができることになる。

また、反射音時間間隔に時間経過による一定の変化が見られな いことから、残響音領域全体の反射音構造の傾向を捉えるために必 要な最小時間幅が得られる可能性が示唆され、残響音領域における 最小時間幅内の反射音から残響音全体の反射音時間構造の傾向を捉 え、これに基づき残響音全体の反射音時間構造を作成する残響音作 成方法が可能になるものと考えられる。

そこで、残響音領域全体の反射音時間構造の傾向を示すことが できる最小時間幅が得られるかについて検討を行った。ここでは、 反射音時間構造に限らず、残響音全体の特性が、最小時間幅を持っ て切り出した反射音群に関しても共通すると考え、両耳におけるコ ヒーレンス関数を用い、残響音全体の傾向を示すことのできる時間 幅を検討の手掛かりとした。なお、検討には同じシューボックス型 ホールの1階中央付近に扔けるタミーヘッド(高研製)による実測の インパルス応答を用いた。

当ホールにおいて、拡散状態に移行したとみなした直接音から 
$180 \mathrm{msec}$. 以降全体、および $180 \mathrm{msec}$. 以降 $50 \mathrm{msec}$. 幅、 $25 \mathrm{msec}$. 幅、 $12.5 \mathrm{msec}$. 幅と切り出す時間幅を次第に狭めていった場合の両耳間 のコヒーレンス関数を图 4 に示す。これを見ると、残響音領域全体 のコヒーレンス関数は、 $100 \mathrm{~Hz}$ 付近で最も高く、高周波数域に向 かって急激に低下し、 $500 \mathrm{~Hz}$ 付近からは0.1 前後と大きな変動はな い。これを、残響音を切り出す時間幅を次第に狭めていった場合の コヒーレンス関数と比較して見ると、切り出す時間幅が短くなるに 従い、主に $500 \mathrm{~Hz}$ より高い周波数においてコヒーレント度が上舁し ている。低周波数域から急激にコヒーレント度が低下し、 $500 \mathrm{~Hz}$ 付 近より高い周波数では変化が小さい、と言う残響音全体のコヒーレ ンス関数の傾向が見て取れるのは50msec. 幅までである。

以上のコヒーレンス関数による検討結果から、残響音全体の傾 向を示す反射音群を切り出すための最小時間幅を $50 \mathrm{msec}$. と仮定し、 この時間幅が反射音時間構造に関して適用できるかを検討した。

図 2 に示したエネルギパルス応答を用い、直接音から $180 \mathrm{msec}$. 以降の反射音を $50 \mathrm{msec}$.ごとに切り出し、反射音時間間隔の度数分 布を求めた。図 $5 に$ に切り出した各時間帯ごとの反射音時間間隔によ る度数分布の例を、その指数回帰曲線と合わせて示す。

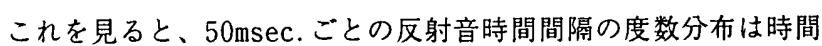
経過によらず残響音全体と同様に指数分布を示している。また、残 響音全体および各時間帯の指数回帰曲線を重ねると、図 6 に示すよ うにほほ一致する。

また、室形状が異なる際にも、残響音全体の傾向を捉えるための 最小時間幅を $50 \mathrm{msec}$ ．とできるかを見るために、ワイシヤード型 ホール $\left(2100\right.$ 席、V=21000 $\left.\mathrm{m}^{3}\right)$ 中央付近における正四面体頂点法によ るエネルギパルス応答を用いて検討した。図 7 にエネルギパルス応 答および残響音領域における反射音時間間隔を、四 8 に残響音全体 による反射音時間間隔の度数分布および $50 \mathrm{msec}$. 幅ごとの反射音時 間間隔の度数分布による回帰曲線を重ねて示す。これらを見ると、 ワインヤード型ホールにおいても、反射音時間間隔による度数分布 は指数分布を示しており、また $50 \mathrm{msec}$.ごとの反射音時間間隔によ る度数分布は、シューボックス型ホールと同様に残響音全体による ものと、ほぼ致している。

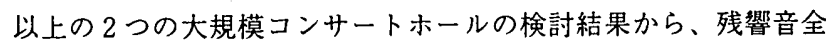
体の反射音時間構造の傾向は、 $50 \mathrm{msec}$. 幅程度のある時間幅におけ る反射音時間間隔の度数分布によって捉えられることが示唆され る。

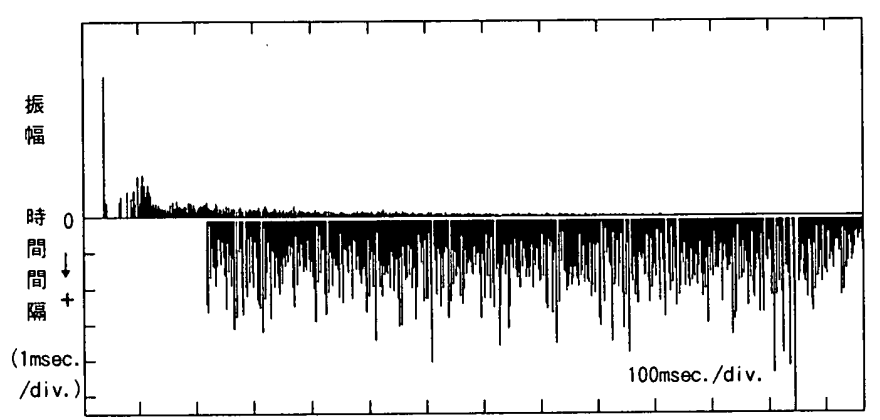

図7 ワインヤード型ホールのエネルギパルス応答および反射音時間間隔
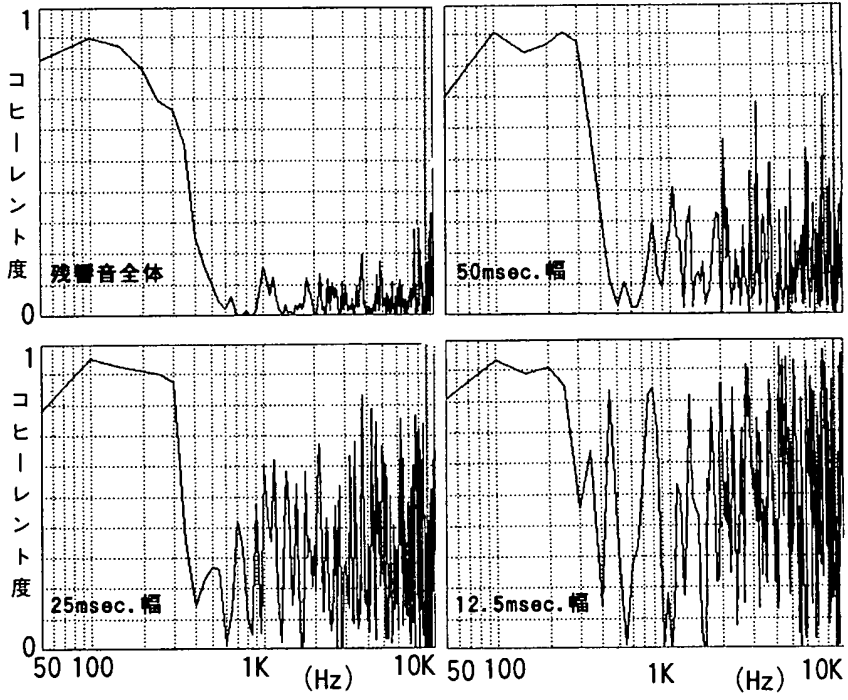

図 4 切り出す時間幅による両耳間のコヒーレンス関数の変化
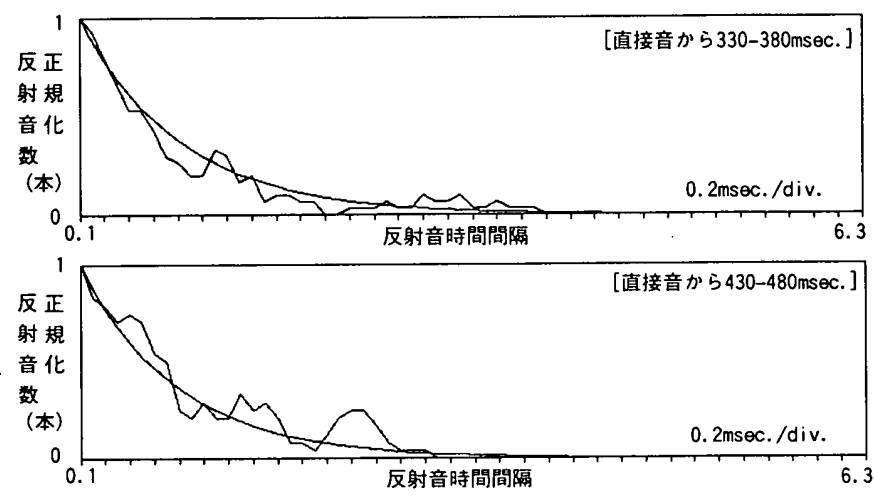

図 5 各時間帯における反射音時間間隔の度数分布

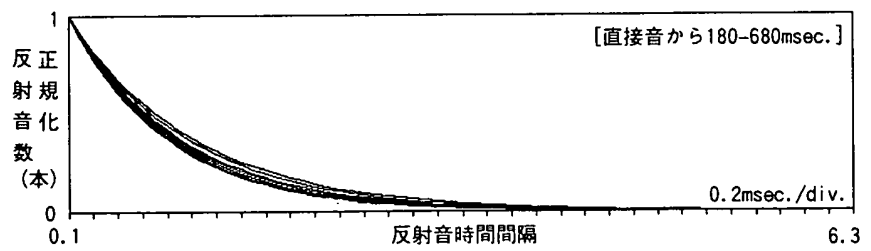

図 6 50msec.ことと指数回帰曲線の比較

[残要音全体]
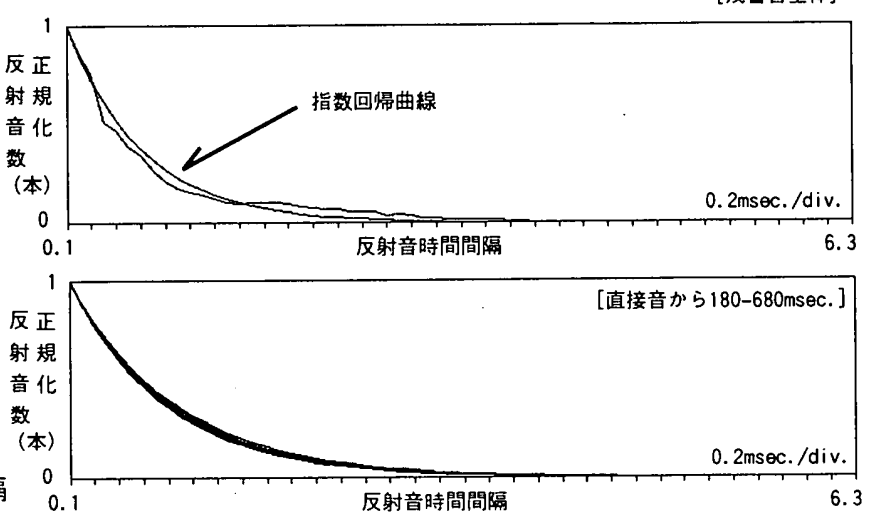

図 8 ワインヤード型ホールの残響音全体の反射音時間間隔の

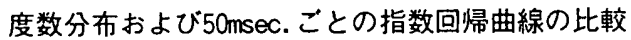


3。残㸷音領域における反射音時間瑇造を考虑した残然音付加手法 3.1 反射音時間構造の作成

残䈉音領域において $50 \mathrm{msec}$. 幅程度で切り出した反射音の反射音 時間間嵒の度数分布から、残郘音全体の反射音時間構造の傾向を示 す反射音構造を作成できる可能性が示された。ここでは、数值シ ミュレーションによる初期反射音への残響音付加が目的であるか ら、計算時間短縮の点から、切り出す時間帯は、拡散状態に移行し たと見なされる直後であることが望ましい。なお、数値シミュレー ション結果から、どのように拡散状態に移行したとする時刻を決定 するかは今後の重要な検討課題である。

図 1 に示したシューボックス型ホールにおいて、短時間指向拡 散度の時間变化が1.0に近づいて安定し、ほほ拡散状態に移行した と見なした時刻 $(180 \mathrm{msec}$. 功 $50 \mathrm{msec}$. 間の反射音時間間隔による 度数分布の指数回帰曲線より、それ以降の反射音時間構造を作成す る手法を検討した。用いた指数回帰曲線を図 9 に示す。

この指数回帰曲線に従う反射音時間構造を作成するため、指数回 缔曲線の時間間隔軸(横軸) と正規化した反射音数軸(縦軸)㧍よび指 㪙回婦曲線に囲まれた面積(図 9 の網掛け部)を反射音の出現確率と 捉え、反射音時間間隔および反射音数を、それぞれ乱数によって独 立に決定し、両者によって示される座標が反射音の出現確率を示す 簛囲内に存在した場合、座標に対応する反射音時間間隔に基づき反 射音位置を逐次時系列上に示していく。なお、乱数は正規化し、各 軸の最大・最小内での値を決定する。

この方法では、反射音の作成に結びつかない多数の試行が繰り返 されるが、コンピュータ上での処理に適しているため、3 秒程度の 反射音位置を決定するのに必要な計算時間は 1 分以下である。ま た、本アルコリズムによれば、反射音時間構造作成の基となる度数 分布は、検討に用いた指数分布である必要はなく、数式化されたも のであればどのような曲線でも適用可能である。

图 10 に、得られた反射音位置および反射音時間間隔を、実測と 同じ表示により示す。また図 11 には、得られた反射音時間間隔の 度数分布と、作成に用いた指数回帰曲線、および $50 \mathrm{msec}$.ごとの反 射音時間間隔による度数分布を示す。これらを見ると、作成した反 射音時間構造は、実測と良い対応を示しており、拡散状態に到達し た時刻から $50 \mathrm{msec}$.までの反射音を用いて、実測の残響音と同様の 傾向を示す反射音時間構造が近似的に作成できるものと考えられ る。

\subsection{S S を用いた音場合成のための頭部伝達関数の考虑}

O S S 等のトランスオーラル系の再生方式に適用するため、前項 の方法により作成した反射音時間構造に基づき、頭部伝達関数を考 虑して而耳への信号を作成した。

残賠音領域において反射音の到来方向に大きな偏りは生じないと 仮定して、前項の方法によって求められた各反射音ごとの反射音の 到来方向を、逐次乱数によって決定し、入射方向に対応する頭部伝 達関数データベースから参照される両耳における応答を、時系列上 に重ね合わせていった。

現在保有する頭部伝達関数は、图 12 に示すように、仰角- 30 度から 60 度までを承平角、仰角とも5 度おきに、また仰角 60 度 から90 度までを 10 度おきに分割し、ダミーヘッド(高研製)を用

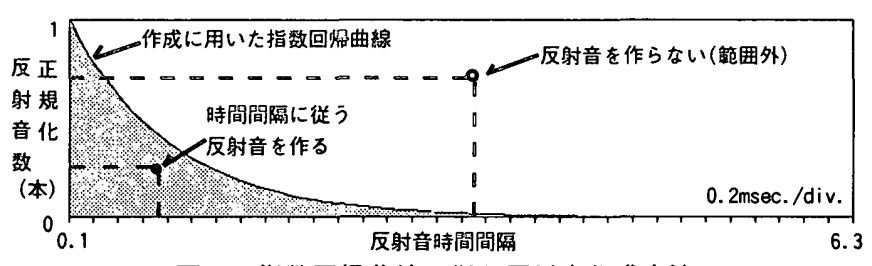

図 9 指数回帰曲線に従う反射音作成方法

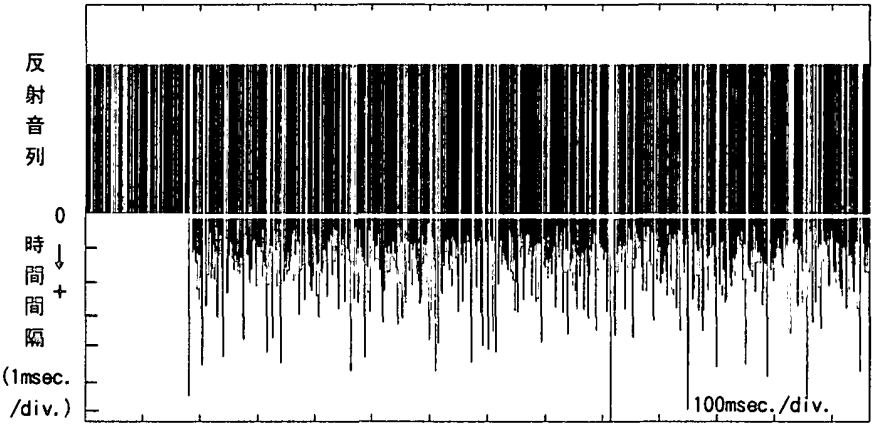

図10 作成した反射音および反射音時間間隔
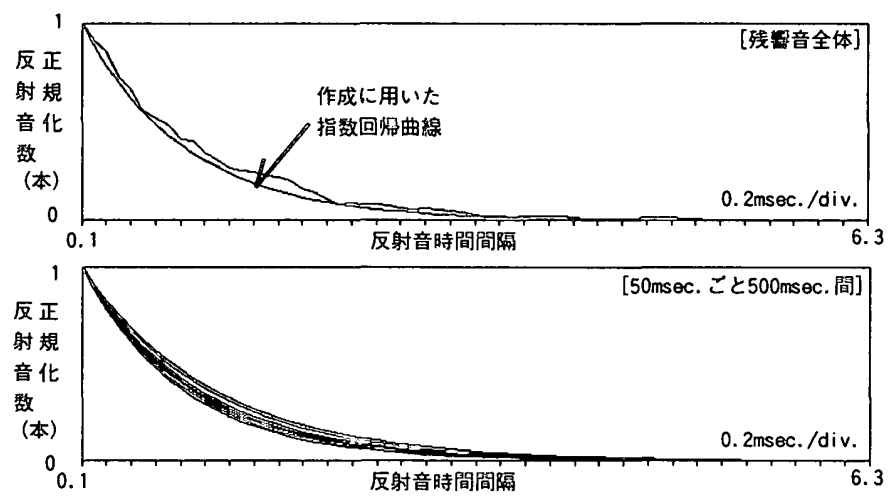

図11 作成した反射音時間構造の時間間隔による度数分布

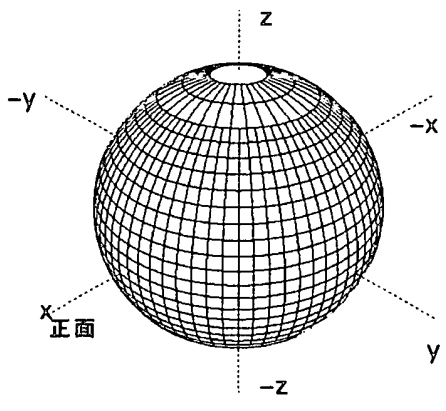

図12 頭部伝達関数測定時の 立体角の分割の様子

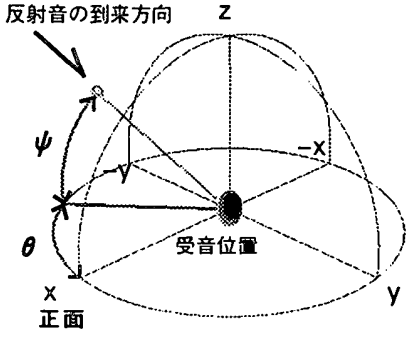

図13 反射音到来方向の決定
いて、無響室において測定したものであり、測定に用いたスピーカ 等の特性は、逆フィルタによって取り除き、データベースを作成し た。

各反射音の到来方向は、図 13 に示すように、水平角 $(\theta)$ およ び仰角 $(\psi)$ を用い、それぞれ乱数により独立に順次決定した。その 際、水平より下方の反射音は周囲の椅子により遮られ反射音として 考虑しにくいものとして、反射音の到来方向は上半球からのみとし た。決定された反射音の到来方向に最も近い頭部伝達関数をデー夕 ベース内より検索し、左右一対のインパルス応答を、作成した反射 音位置に従い両耳への反射音として時系列上に順次重ね合わせて いった。 


\section{3 残響音周波数特性の簡易的予測}

数值シミュレーションにより初期反射音の周波数特性が予測され ていれば、初期反射音との整合性を確保するため、付加する残響音 においても周波数特性の時間変化を考慮する必要がある。残響音周 波数特性の時間変化を詳細に予測しょうとすると反射音時間構造と 同様に多大の計算時間が必要になり、残響音付加による計算時間短 䋧が図れなくなる。そこで、残響音領域における拡散音場を仮定 し、空気吸収および壁面の吸音による周波数特性の時間变化を簡易 的に予測した。

単一周波数における空気吸収の影響は、ISO/DIS 9613/1に示され る減衰率 $\mathrm{m} 、$ 伝搬距離 $\mathrm{x}$ より、1 式で表される。また、単一周波数 における壁面の吸音の影響は、反射回数 $\mathrm{n}$ および平均吸音率による 2 式を用いた。

$$
\begin{aligned}
& I=I_{0} e^{-m x} \\
& I=I_{0}(1-\bar{\alpha})^{n}
\end{aligned}
$$

また、時間による周波数特性の変化を考慮するため、 $50 \mathrm{msec}$.ご とに、空気吸収および壁面の吸音それぞれによる各周波数ごとのエ ネルギを算出し、これに基づき4096タップ（サンプリング周波数： $48 \mathrm{KHz}$ ）の直線位相フィル夕を作成して、前項までの方法により作 成した左右一対の信号に順次畳み込んだ。この時、時間経過に伴い 吸音等による減衰が生じるが、簡易的に $50 \mathrm{msec}$.ごとに周波数特性 を与えているため、その減衰の様子は階段状であり、残響音として の滑らかな減衰が得られない。そこで、残響時間に従う減衰を周波

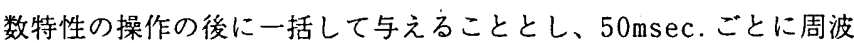
数特性を畳み込んだ後の実効值が、分割した各時間帯でほほ等しく なるように振幅を操作し、全体としてほほ定常的な左右一対の信号 を得た。なお、吸音率データは、1/1oct.ごとのデータをスプライ ン補完した。

得られた定常的な左右一対の信号は空気吸収と壁面の吸音による 周波数特性の変化が考慮されていることになる。そこでこの一対の 信号に残響時間による指数隇衰を与えた上で、初期反射音に付加す る。その際、初期反射音との波形の不連続によるクリック等の異音 の発生を防ぐため、図 14 に示すように、12.5 msec. 幅のコサイン カーブにより初期反射音部を滑らかに収束させ、また残響音部に同 様にコサインカーブによる立ち上がり部を設けている。さらに、重 ね合わせる $12.5 \mathrm{msec}$. 幅での実効值が残響音を重ね合わせる前と変 化ない様に、残響音全体の振幅を操作した。

\section{4. 残響音付加手法に関する比較聴感実倹}

提案した反射音時間構造を考慮した残響音付加手法の有効性の検 討のため、ダミーヘッドを用いて測定した両耳でのインパルス応答 の初期反射音に、提案した手法により作成した残響音を付加し、実 測による音場との差異について比較聴感実験をおこなった。実験は これまで検討に用いてきたシューボックス型ホールの 7 点（図１５） を対象とし、図 2 に示した正四面体頂点法による測定結果による反 射音時間構造を用いて残響音を作成した。また、比較のため、反射 音時間構造および頭部伝達関数を考慮しない信号として両耳におけ るコヒーレント度を操作したホワイトノイズ7、、反射音の到来方向 による頭部伝達関数は考慮するが反射音構造を考慮せず $20 \mu \mathrm{sec}$.ご

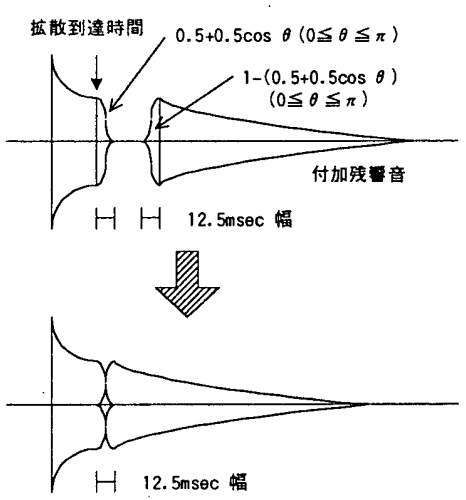

図14 残響音接続方法

表 1 比較音場の種類

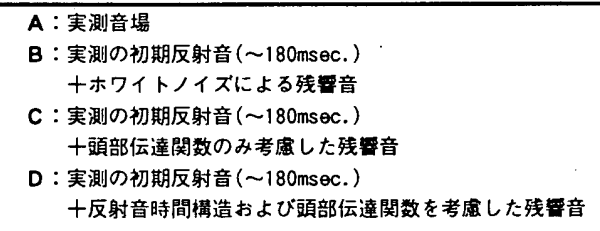

表 2 評価項目

どちらの音堨が

1. 音色の連続性が得られているか

2. 自然な減衰が得られているか

表 35 段階の評定尺度
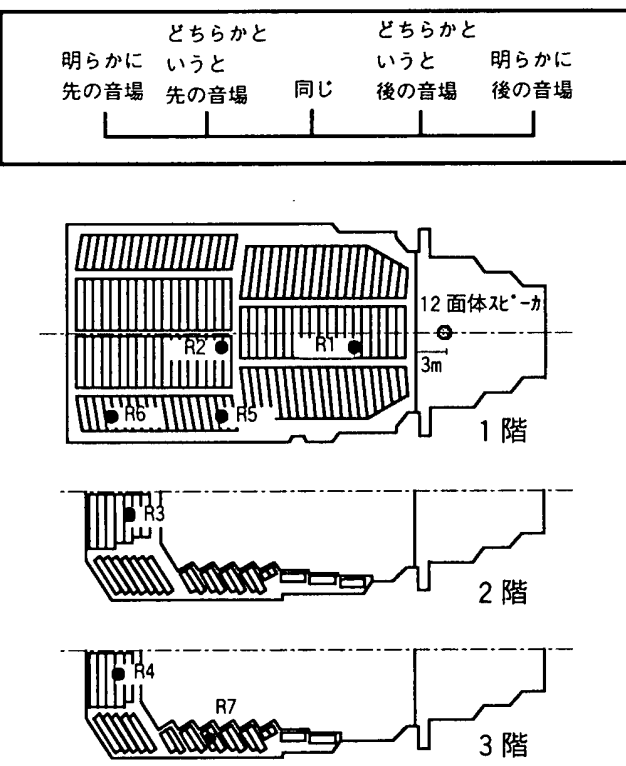

図15 測定点位置

との等間隔に反射音を時系列上に並べた信号を用い、それぞれ周波 数特性時間变化を考慮した残響音を作成した。なお、これらの残響 音成分は実測による初期反射音に接続するため、測定に用いた 12 面体スピーカの特性を別途畳み込んだ。比較聴感実験に用いた 4 音 場を表 1 に示す。

各音場の物理的特性を比較して、測定点 R 3 における直接音から $600 \mathrm{msec}$. 位置での周波数特性を図 16 に、残響音全体でのコヒーレ ント度を図 17 に示す。図 16 を見ると、簡易的予测による残薌音 
の周波数特性は、いずれも実測とよい対応を示しているが、頭部伝 達関数を考慮した場合、わずかではあるが $5 \mathrm{KHz}$ 付近のレベルがホ ワイトノイズに比べて高く、より実測に近い特性となっている。ま た、圆 17 のコヒーレンス関数を見ると、反射音構造を考虑した残 響音が最も実測に近い特性を示している。

残響音に関する比較聴感実験を行う際に、継続する楽音を用いる と、繼続部の印象が強くなり、付加した残響音の種類による違いが 聴き分けにくくなる恐れがある。そこで、音源には無響室のオーケ ストラ曲(オペラ「ルスランとリュドミラ」序曲買頭0.2秒)による 短音を用い、音源を実測および残響音を付加したインパルス応答に 畳み込んだ後、イヤースピーカ8)を用いたOS Sにより、無響室に おいて再生した。実験は一対比較法により、4 音場を 2 秒の間隔を おいて対とした 12 対を作成し、回答の信頼性をチェックするため の同一音場同士の 4 対を加えた合計 16 対について、表 2 の評価項 目について、表 3 の 5 段階のカテゴリによって評価させた。回答時 間となる対と対の間隔は 7 秒である。聴取レベルは約 $65 \mathrm{~dB}(\mathrm{~A})$ 、被 験者は成人男女 17 名とした。なお、イヤースピーカによる音場合 成の際に、パターン化した正面頭部伝達関数補正データを用い正面 方向の定位改善91を図った。実験を通して、同一音場対に対して 「明らかに先・後」と一度でも評価した 2 名の回答を除き、15名 の回答結果についてシェッフェの一対比較法10)を用いて分析し
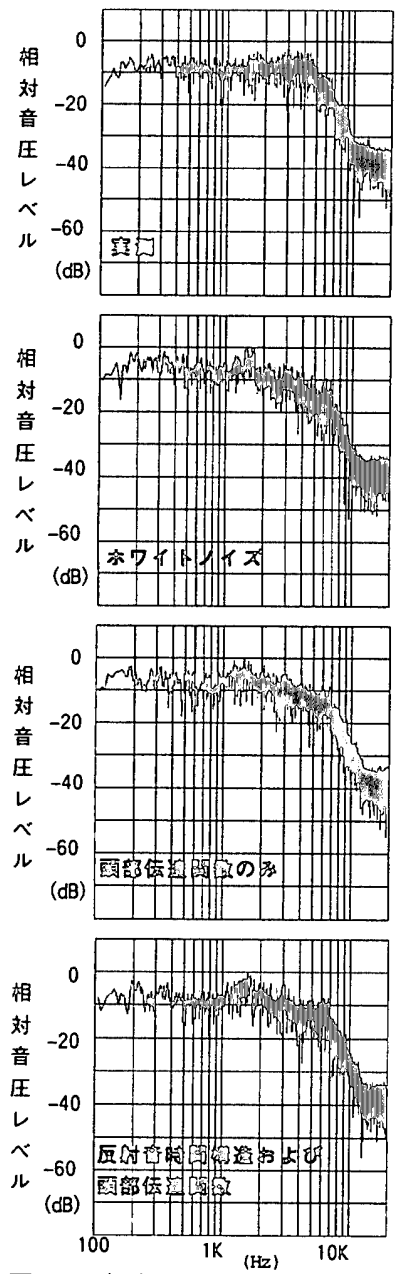

图16実駼に用いた 4 音場の残維 音領域における周波数特性比䩙
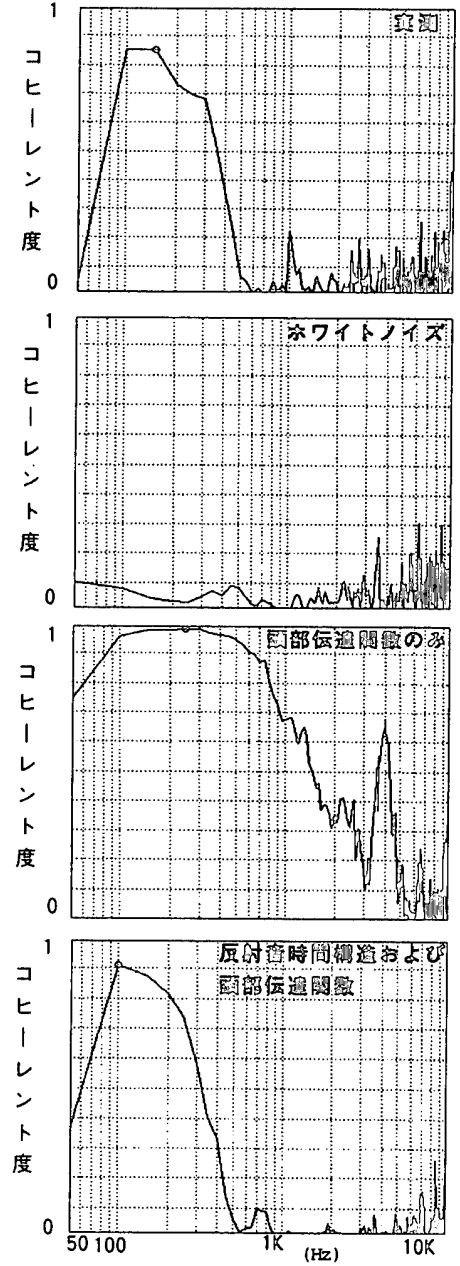

图17実験に用いた 4 音場の残鱀 領域におけるコヒーレント度比暲
た。得られた各受音点における 4 音場に対する心理尺度構成值を图 18 に示す。

图 18 の全体的な傾向を見ると、実測音場 $\mathrm{A}$ が聴感上最も自然な 音場として評価されているが、反射音時間構造および頭部伝達関效 を考歷した音場 $\mathrm{D} は 、$ 実測音場 $\mathrm{A}$ と同程度の評価が得られている。 頭部伝達関数のみを考虑した音場 Cは、周波数特性等は反射音時間 構造を考慮した音場 D と同様であったが、実測音場 $\mathrm{A}$ とは聴感上有 意な差が生じており、反射音時間構造が聴感に与える影響が大きい ことが示されている。

今回の検討では、正四面体頂点法による R 2 付近の測定データか らの反射音構造を作成し全受音点に適用させたが、 $\mathrm{R} 7$ を除く、い ずれの受音点においても音場 D は良好な評価が得られており、反射 音時間構造および頭部伝達関数を考虑した残響音付加手法の有効性 が示されたと考えられる。

$\mathrm{R} 7$ は他の受音点と異なり、音場 $\mathrm{A}$ と音場 $\mathrm{D}$ に聴感上有意な差が
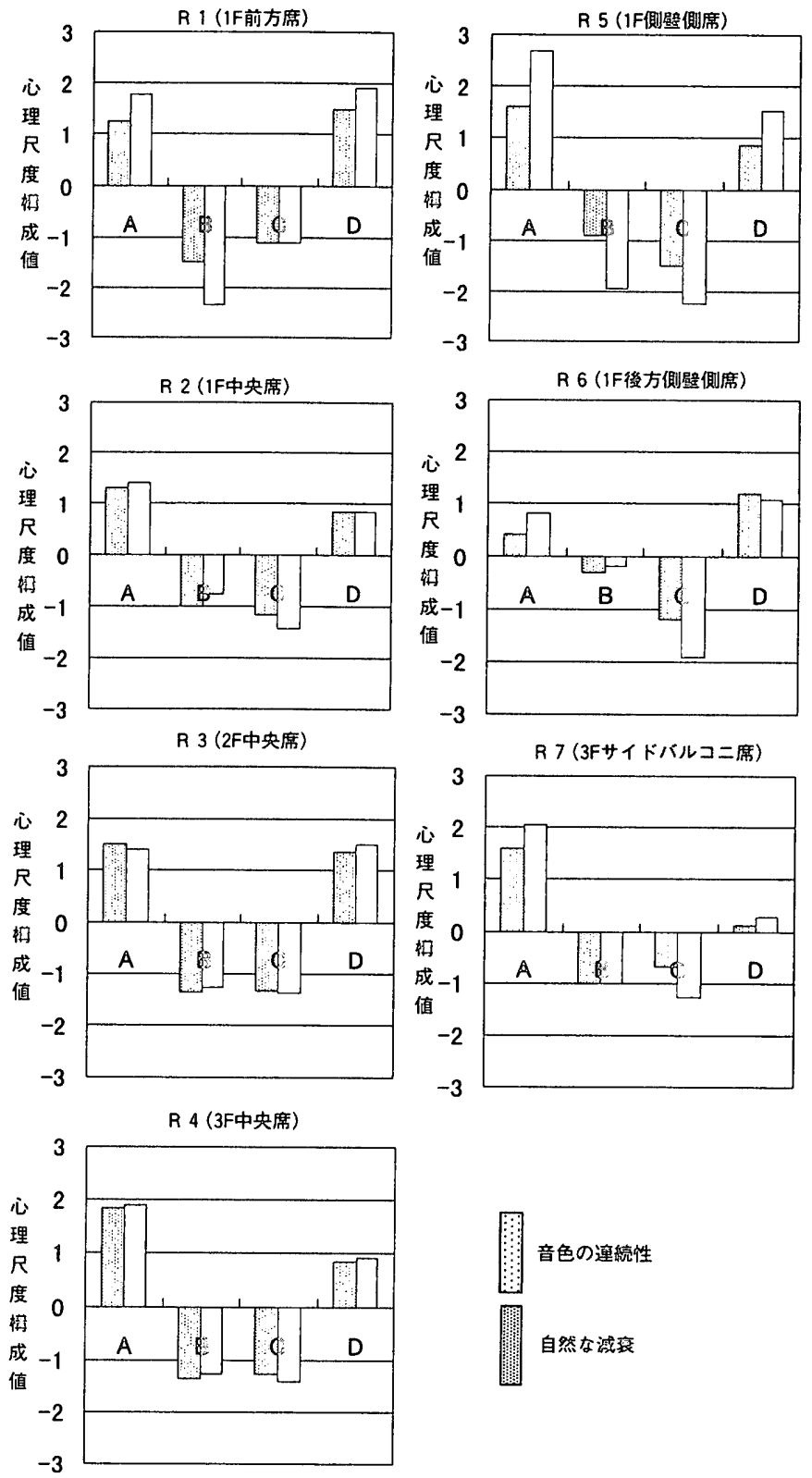

図18４音場に対する心理尺度慍成值の対応 
生じている。この受音点 $\mathrm{R} 7$ は側壁やバルコニ等により、反射音の 偏りが生じやすい位置にあり、反射音の到来方向を受聴者を中心と した上半球の範囲内で均一になるようにしたことが、音場 Dの評価 を下げる原因となったと考えられる。また、音源が見下げる位置に ある $3 \mathrm{~F}$ 中央付近の $\mathrm{R} 4$ においても、 $\mathrm{R} 7$ と同様に反射音の到来方 向を均一に設定した影響が見られる。

なお R 6 は測定時にS N 比を確保しにくい位置にあり、実測のイ ンパルス応答の残響後部にノイズが含まれていたため、実測音場 $\mathrm{A}$ に比して、反射音時間構造および頭部伝達関数を考慮した残響音を 付加した音場 Dの方が、より自然な音場として評価されている。木 ワイトノイズから作成した残響音を付加した音場 Bと実測音場 $\mathrm{A} の$ 聴感上の差が小さくなったのも、実測に含まれていたノイズの影響 と考えられる。

以上の比較聴感実験の結果、反射音構造を考虑した残響音付加手 法の有効性を確認することができた。今後、反射音の偏りが生じる 受音点に対しては、反射音の入射方向の偏りを含めて、検討する必 要があると考えられる。

\section{5.まとめ}

O S S 等のトランスオーラル系による数值シミュレーションから の音場合成に必要な全時間インパルス応答の計算時間短縮のため、 初期反射音と残響音の整合性を確保する反射音時間構造および頭部 伝達関数等を考慮した残響音付加手法を提案し、比較聴感実験を通 して手法の有効性を示した。今後、残響音領域における反射音到来 方向の偏りの問題、残響音を付加する時刻の設定についてさらに検 討していきたい。
謝辞

O S S 導入にあたって、ご指導を受けた東京電機大学名誉教授 三浦種敏先生、東京電機大学教授 浜田晴夫先生に感謝の意を表 します。

\section{参考文献}

1) 坪井、渡辺、平野：波動性を考慮した室内音場シミュレーションシステム日 本建築学会技術報告集、第 2 号、p. 121-126, 1996年3月

2)浜田晴夫：基準的収音・再生を目的とする0rthostereophonic Systemの構成 日本音罂学会誌 vol. 39,p. 337-348(1983)

3)高宮嗣昌、岸永伸二、川上福司：カオスを仮定した昖散過程の乱数シミュ レーション 日本音響学会講演論文集、p831-832、平成 8 年 3 月

4)西 隆司、北村浩一、福西 達：後部残響音付加に関する一検討 日本音製 学会講演論文集、p843-844、平成 9 年 3 月 5)関口克明、木村翔、羽入敏樹、松本英一郎：4チャンネルマイクロフォンシス テムを用いた正四面体頂点法による室内音場の解析 日本建築学会計画系論文集、 №414, p. 1-11(1990)

6)羽入敏樹、木村翔、橋本修、坂本吉宏：音場の過渡応答に着目した拡散性の 検討 日本建築学会計画系論文集、No.471, p. 11-18(1995)

7)渡辺充敏、木村翔、山口順、平野滋：残響音付加手法の違いによる実測音場 との聴感上の差異の検討、日本建築学会講演梗概集、p. 213-214(1996) 8)吉田実、下平美奈子、三浦種敏、浜田晴夫：イヤースピーカを用いた新しい O S S 再生方式 AES東京コンベンション'91 予講集、p. 138-141(1991) 9)山口順、木村翔、渡辺充敏、平野滋：頭部近傍に設置したスピーカによる音 場再生手法の検討、日本建築学会講演梗慨集、p. 211-212(1996) 10)芳賀敏郎、憍本茂司：実験デー夕の解析(1) 日科技連

（1997年 4 月10日原稿受理，1997年 8 月20日採用決定） 